\title{
An Overview: Approaches for the Development of Basic IT Skills
}

\author{
Syed J. Naqvi \\ College of Commerce and Economics, Sultan Qaboos University \\ Al-Khod, Sultanate of Oman
}

\author{
cce3249@squ.edu.om
}

\begin{abstract}
There is a growing importance of computerization, information flow and the tremendous use of Information Technology (IT) in all the fields including business, education, government and medicine. The significant improvements in IT continue to occur at an ever-increasing pace. The speed, size, cost, and capabilities associated with computers and telecommunications provide a wealth of highly attractive opportunities for using this technology to help solve business problems or enhance current ways of doing business. There is a general recognition that students in secondary, further and higher education need to acquire IT skills that match the IT needs of the contemporary businesses.
\end{abstract}

The major focus of this investigation concerns the development of IT skills among new entrants to the institute of higher learning to meet the changing needs of IT, especially in the businesses environment. Traditionally, the introductions to IT courses offered in the past were through the programming languages. There seems to be a trend to acquire IT skills moving away from programming and getting skills through off-the- shelf software packages. There are many reasons for this, including the availability of powerful and user-friendly software, such as word processing, databases and spreadsheets, which have raised the level of expectations in the use of IT for business and removed the need to learn to write computer programs in a traditional block structure language.

If the software packages are considered, then the obvious question, "What should be the order of their presentation in a basic IT course?" emerges. The popularity of the Internet and its use in the business environment has made it necessary be included in the introduction to computers course. This paper explores several possible approaches for the acquisition of basic IT skills among new IT enthusiasts and proposes an Information Systems Approach for the acquisition of basic IT skills used in business.

Keywords: Information Technology, Information Systems, Programming, Computer Education, Business Software, Internet and Internet Publishing.

Material published as part of this journal, either on-line or in print, is copyrighted by Informing Science. Permission to make digital or paper copy of part or all of these works for personal or classroom use is granted without fee provided that the copies are not made or distributed for profit or commercial advantage AND that copies 1) bear this notice in full and 2) give the full citation on the first page. It is permissible to abstract these works so long as credit is given. To copy in all other cases or to republish or to post on a server or to redistribute to lists requires specific permission from the publisher at Publisher@InformingScience.org

\section{Introduction}

The significant improvements in IT continue to occur at an ever-increasing pace. The speed, size, cost, and capabilities associated with computers and telecommunications provide a wealth of highly attractive opportunities for using this technology to help solve 
business problems or enhance current ways of doing business.

It is nearly impossible to run a competitive business without a computerized Information System. From a business perspective, IT can be summarized as a range of technologies to capture, store, process and transmit information in support of business activities. Computers are considered as tools for processing information. Information Technologies, at the same time, are tools and techniques, which support the design and development of Information Systems including hardware, software, databases and telecommunications. Companies that can integrate various technologies to achieve business goals are often very successful (Gupta, 1996).

Information Technology in its narrow definition refers to the technological side of an Information System. Information Systems are defined technically as a set of interrelated components to collect (or retrieve), process, store, and distribute information to support decision making and control in an organization by using software tools such as word- processing, database management, graphics and spreadsheets modeling (Birnbaum, 1989; Laudon \& Laudon, 2003; Turban, 1996).

Indeed, the importance of IT in business organizations warrants its study. In recent years it has been recognized that the success of a business organization largely depends, not only upon IT, but also upon the way in which its workers use it. These organizations need workers with more IT skills and not just with data entry or word-processing expertise.

Students of today need to be able to understand and apply this technology to be more proficient in IT skills used in business. There is a general recognition that students in secondary, further and higher education need to acquire IT skills, and that these IT skills should include word processing, spreadsheets, graphics and databases (Freeman \& Rowley, 1995; Rowley \& Coles, 1996).

The implications of IT for all walks of life have posed many important issues and possible avenues for investigation. One of the important issues is to explore different ways of acquiring the IT skills used in business. The major focus of this investigation is to provide an overview of different approaches used in delivering IT skills to new entrants in the institute of higher learning and possibly suggesting a suitable approach to meet the changing needs of IT in business.

\section{IT and Educational Institutions}

In July 1996 an international conference "International Conference on the Place of IT in Management and Business Education" sponsored by the International Federation for Information Processing (IFIP) was held in Melbourne, Australia. This examined IT education programs at all levels in different educational institutions around the world including Australia, Finland and China.

Most undergraduate courses in Australian universities designed to develop managers and accountants are structured around 24 subjects, or units, and include a single compulsory unit in information technology, which constitutes less than 5\% of the total subjects offered. Hewett (1997) has suggested that general business students need to take additional relevant IT units and the courses should be more application-oriented than technical.

In China the business management students are offered a single subject regarding business IT knowledge - "Modern Management Information Systems" - and the credit for this course is only about one-tenth of the total credits (Shan, Jun, \& Tong, 1997). The BBA students in Finish universities earn at most 7 credits for IT or only approximately $5 \%$ of the total credits required for a degree program. Paturi (1997) argued that this $5 \%$ of the total is not sufficient for a future professional in the information society.

The situation in Oman is very similar to that described above. In Oman the College of Commerce and Economics at the Sultan Qaboos University offers a 124 credit B.Sc. degree in business dis- 
cipline. Only six credit hours are allocated for compulsory IT courses, which constitutes only about $5 \%$ of the total degree program.

By looking at the business degree programs of many universities as described earlier, it appears that the compulsory IT courses offered are minimal. Approximately $5 \%$ of the total credits are reserved for IT courses. Researchers such as Paturi (1997), Hewett (1997) and Shan et al. (1997) believe that if students are to be prepared to meet the challenges of the contemporary business world, the credits or the IT courses offered to business students are too few and needed to be increased. The additional courses should be based on advanced digital technologies used in business, and students are urged to acquire these skills to prepare them better to understand and see the role of these technological advancement in modern business practices.

Whilst it is obviously desirable to increase the amount of time and credits devoted to IT, this would involve a major restructuring of the courses, which is beyond the scope of this researcher's influence. Consequently, this study, rather than proposing new curriculum, examines how the traditional introductory IT course can be made more effective in developing the IT skills of learners. For this purpose we are now going to examine different approaches followed in educational institutions. Most universities, in their business degree programs, have an 'Introduction to IT course', offering either an introduction to programming languages or software packages to develop the IT skills of their students. The obvious question to emerge is what should be introduced in an introductory IT course? If we choose packages such as word-processing, spreadsheets/graphics and databases then how should we teach about them?

\section{Development of IT Skills through Programming}

In the early days doing something with computers as part of computer literacy education was only possible by teaching programming; being able to program meant being able to apply the computers (Luehrman. 1981). A person who wants to write a computer program for himself would probably use some higher level languages like Fortran, Cobol and presently be using Visual Basic, Java, $\mathrm{C}$ or $\mathrm{C}++$ etc. However, a move away from this approach has occurred. There were many reasons for this, including: the power of today's off the shelf software, demands of the job market, and lesser programming requirements (Payback \& Herrmann. 1995).

We have witnessed the trend since the late 1980s away from programming and towards the use of software packages. The proliferation of more powerful microcomputers and user-friendly software for such tasks as word-processing, databases and spreadsheet applications has raised the level of expectation for students and removed much of the motivation for learning to write their own computer programs in a traditional programming language.

The work of many researchers such as Hunter (1984) and Plomp and Van de Wolde (1985) suggested introducing software packages in an introductory IT course in place of programming. There is a general recognition that students in secondary, further and higher education need to acquire some IT skills, and that these IT skills should include word processing, spreadsheet, graphics and database skills (Hunter, 1984; Plomp \& Wolde, 1985; Rowley \& Coles, 1996).

At present, a first computer course offered at any typical institution of higher learning includes these three popular business software modules. (Freeman \& Rowley, 1995). As mentioned earlier, the question is, if we choose these productivity tools instead of programming languages to introduce IT, what should be their order of presentation? The answers to this have significant implications for the design and content of the course. These issues are addressed in the following sections, starting with the development of IT skills through business software. 


\section{Development of IT Skills through Business Software}

As mentioned earlier, the development of IT skills through business software could be offered by one of the three trivial approaches. These approaches are designed to develop IT skills of students at all levels of education, and usually begin with some level of computer literacy (education), followed by one of the following:

- Word-Processing First Approach

- Spreadsheets First Approach

- Databases First Approach

More details on each of these are now provided.

\section{Word-processing First Approach}

The word-processing First Approach is also known as the Traditional Approach (TA) and follows the following sequence.

- Computer Concepts

- Word-Processing

- Spreadsheets

- Graphics

- Databases (not always)

The Word Processing First Approach has been widely adopted at all levels of education for teaching IT skills from schools through colleges and into higher educational institutions. The reason for this being that, in general, word-processing is perceived to be a straightforward IT application, easy to learn and apply in any office work environment.

In the researcher's opinion many IT instructors teach computer literacy along with business software in their first introduction to computer courses for business students and do not teach information literacy, which is needed in the contemporary business world. Computer literacy focuses more on the study of computers, their technicalities and functions, while information literacy deals with the study of applications of computers for handling information in support of business activities. Many instructors appear to lack knowledge of business activities and feel difficulty in relating computer learning with the overall IT applications in business and often lean towards teaching computer literacy in an Introduction to Computers in business course in place of information literacy.

In TA the word processing has been so dominant that information technology has been regarded in some circles as synonymous with word-processing. Some of the central concepts of information systems and their wider applications (in business) are never drawn to student's attention.

Burgess and Tatnall (1997) conducted their Pre-and-Post-study research on an IT course, which was taught to MBA students at Victoria University of Technology in Australia, with three major goals:

- to provide students with adequate PC literacy skills

- to provide students with a basic understanding of the role of IT personnel

- to provide students with a basic understanding of the contribution that IT can make to the business 
The result of the survey conducted at the conclusion of the course indicated that the vast majority of students gained an increased level of IT knowledge with high usage of word- processing followed by spreadsheets and databases.

Blackmore (1992) conducted a study on student teachers at Liverpool Polytechnic where they were introduced to IT applications such as word-processing, spreadsheets and databases on a selflearning basis. The students had improved significantly in word-processing as compared to database and spreadsheet skills.

Freeman and Rowley (1995) argued that in introducing IT through TA, where word-processing dominated so much that the students gained more skills in word-processing but did not progress well with IT skills in follow-up modules like spreadsheets and databases. Moreover, the TA does not introduce the concepts of Information Systems as a wider application of IT used in business; where as high skills in word-processing is not a paramount need of contemporary business organizations and challenge lies with information-handling skills. These shortcomings of TA warrant us exploring other approaches.

\section{Spreadsheets First Approach}

The Spreadsheets First Approach (SFA) model introduces the modules in the following sequence:

- Computer Concepts

- Spreadsheets

- Graphics

- Word-Processing

- Databases (not always)

Not many instructors follow the SFA. Those practitioners who view computers as the main tools for quantitative data processing and, therefore, give priority to introducing students to spreadsheets use this approach.

The students once again find a short training session very productive and start using the skill gained in computing with numerical data processing. The attractive features of spreadsheets include an automatic recalculation option and graphical capabilities, which inspire some instructors to introduce this IT module first as an appreciation of IT capabilities to new learners.

SFA may emphasize quantitative data processing so much that the other capabilities of IT, such as databases and word-processing, may never be drawn to users' attention fully. However, the needs of the business organizations are information, which could be in quantitative or qualitative format. As with TA, the SFA also gives only a limited exposure to the IT capabilities of computers in support of business activities to their learners.

\section{Databases First Approach}

In Database First Approach (DFA), after an initial introduction to computer concepts and IT in business, this approach starts with databases followed by spreadsheets and graphics and finally word-processing. The essential characteristics of this approach are that it focuses on the quantitative and qualitative information commonly used in business environments. This approach is more in line with the IT applications used in businesses as compared to TA or SFA.

The DFA presents the IT modules in the following sequence:
- Computer concepts
(Computer concepts and IT in business) 
- Databases

- Spreadsheets

- Graphics

- Word-Processing earlier in other packages)
(Data storage and Retrieval)

(Data analysis)

(Data Presentation)

(Data Presentation: integrating tables, charts, graphs as created

Most business organizations collect data, quantitative and qualitative, and proceed to convert these data to information for decision-making and reporting. As described earlier, the TA, the most common approach at all levels of IT education, is mainly dominated by qualitative data, while the Spreadsheets First Approach focuses on quantitative data. Both these approaches provide limited applicability of IT in support of business activities.

On the other hand, according to Freeman and Rowley (1995), the Database First Approach is driven by our belief that information is not simply quantitative and that students and managers need to understand how to use both qualitative and quantitative information, and, in particular, how to interpret and integrate the use of this information in the decision making process.

With the advent of Internet and globalization, accessing and publishing business information become vital skills needed in modern business setups. Keeping this in mind the Information Systems Approach is proposed and described in the following section.

\section{Information Systems Approach}

The Information Systems Approach (ISA) is closer to the Database First Approach and proposes that Internet and Internet publishing be considered to be introduced as the last module in the course. The Information Systems Approach could lead the students towards information handling skills, a vital business activity in modern organizations in a global environment. In general, there are five major IT related activities in business organizations such as Data storage and retrieval, Data analysis and processing, Data Presentation, Data reporting and Data publishing. To be proficient in these activities one should acquire skills in IT modules be offered in the sequence as shown in Table 1.

Table 1. Business Activities and ISA Model

\begin{tabular}{|l|l|}
\hline Business Activities Sequence and IT needs & Acquisition of IT Skills Through ISA sequence \\
\hline Data storage and retrieval & Databases \\
\hline Data analysis and processing & Spreadsheets \\
\hline Data presentations & Graphics \\
\hline Data reporting & Word Processing \\
\hline Data publishing & $\begin{array}{l}\text { Use of Internet for Accessing and } \\
\text { Publishing information }\end{array}$ \\
\hline
\end{tabular}

The ISA begins with conceptual understanding of computer systems and IT in business introduces modules in sequence like databases, spreadsheets, graphics and word-processing followed by Internet and Internet publishing. The modules presented in the course support these activities. The ISA appears more in line with the business activities in modem organizations (Naqvi, 2002).

These software modules are vital for businesses and, if presented in the sequence of the ISA model as shown in Table 1, appear more logical and in order. With these concepts and understanding learners may relate their learning with the IT needs of the business organizations. This 
may lead to a greater appreciation of the role of this software in business, and students are encouraged to acquire more IT skills.

This approach encourages students to consider information first and then to progress to tools for its analysis, presentation and dissemination. This is more in keeping with developing an appreciation of the way in which information systems are used in business.

\section{Conclusion}

IT courses are offered in higher educational institutions around the world. There are concerns regarding the credit hours allocated for IT, which constitute approximately $5 \%$ of the total credits required for a first degree in the business discipline. The literature search suggested that if students are to be prepared to meet the challenges of the contemporary business world, the credit and the IT courses for business students needs to be increased.

The IT courses were offered in the past using programming languages, but with the proliferation of personal computers and user-friendly software, IT courses are offered using off-the-shelf software. At present, the Traditional Approach is the most common approach practiced in the institution of higher learning, but concerns are raised, as shown in the literature, that this approach is more word-processing-dominated where other IT capabilities are never drawn to users' attention related to information handling for business applications. The Information Systems Approach is proposed to deliver more IT skills not only in word-processing, but also in spreadsheets/graphics and databases and information dissemination applications in support of business activities through Internet skills.

The information system approach offers new users of IT more realistic perspective on the contribution IT can make to the effective operation of business and also offers a platform from which it is possible to demonstrate the links between these modules and offer a fully integrated approach. The students learning IT through ISA have great appreciation of the role of this software in business and thus are encouraged to acquire more IT skills.

\section{References}

Birnbaum, I. (1989). Information technology and the national curriculum: Some fundamental issues. Resource, Doncaster. In IFIP, World Conference on Computers in Education 95 (WCCE95), 420-421.

Blackmore, M. A. (1992). The Liverpool scene: New students (1990 to.1991) experiences knowledge and attitude towards information technology. DITTE, 1, NCET, 42-59.

Burgess, S. \& Tatnall, A. (1997). Information technology for managers: Australian generic MBA programs, TC3 WG3.4. In IFIP, International Conference on the Place of Information Technology in Management and Business Education, 35-41.

Freeman, M. \& Rowley, J. (1995). An information systems approach to teaching IT skills. Computer Education, 80, 5-7.

Gupta, U. G. (1996). Management information systems A management perspective. New York: West Publishing.

Hewett, W. G. (1997). The whys and whats of an IT specialization within a generalist management tertiary education, TC3 WG3.4. In IFIP, International Conference on the Place of Information Technology in Management and Business Education, 76-84.

Hunter, B. (1984). My students use computers. Reston, VA: Reston Publishing.

Laudon, K. C. \& Laudon, J. P. (2003). Essential of management information systems: Organization and technology. Englewood Cliffs, NJ: Prentice Hall. 
Luehrman, A. (1981). Computer literacy-What should it be? The Mathematics Teacher, 74 (9), 682-686.

Naqvi, S. J. (2002). Practicing information systems approach for developing information technology skills used in business. Journal of Research on Technology in Education, 35 (1), 97-106.

Naqvi, S. J. (2004). Introducing ISA for acquiring IT competence needed for business applications. Journal of Information Systems Education (JISE), 15 (1), 79-86. Publication of the Association of Information Technology Professional (AITP).

Paturi, T. (1997). Information technology studies in higher business and management education, TC3 WG3.4. In IFIP, International Conference on the Place of Information Technology in Management and Business Education, 76-84. London: Chapman \& Hall.

Plomp, T. \& Wolde, J. van de. (1985). New information technology in education: Lessons learned and trends observed. Europe Journal of Education, 20, 243-244.

Popyack, J. L. \& Herrmann, N. (1995). Why every one should know-how to program a computer. Proceedings of the sixth IFIP World Conference on Computers in Education, 604-605.

Rowley, J. E. \& Coles, S. (1996). The next step: Acquiring more advanced information technology skills, Computer Education, 83, 8-10.

Shan, F., Jun, C., \& Tong, L. (1997). Information technology in China, TC3 WG3.4: In IFIP, International Conference on the Place of Information Technology in Management and Business Education, 47-51. London: Chapman \& Hall.

Turban, E., McLean, E., \& Wetherbe, J. (1996). Information technology for management: Improving quality and productivity. New York: John Wiley Press.

\section{Biography}

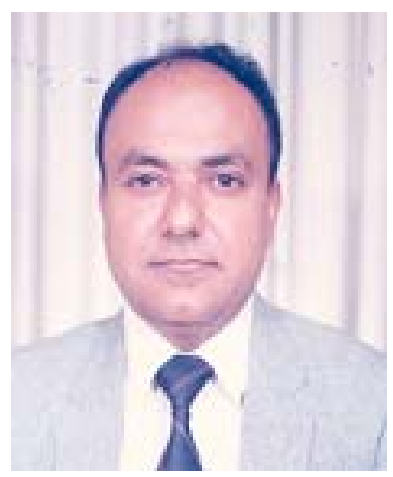

Syed J. Naqvi is an Assistant Professor in the Department of Information Systems, College of Commerce and Economics at Sultan Qaboos University. He received M.S. from East Texas State University and a Ph.D. from University of Birmingham. His teaching interests include programming languages, Web applications development and ecommerce with research interest in computer education. 